\title{
O drama histórico de Almeida Garrett: o presente à luz alegórica e exemplar do passado
}

\author{
Edson Santos SILVA ${ }^{1}$ \\ Universidade do Centro-Oeste do Paraná - UNIOESTE
}

Garrett foi, sem dúvida, um homem comprometido com seu tempo, seja por participar ativamente na implantação do Liberalismo, seja por procurar renovar as letras portuguesas, introduzindo o Romantismo, em 1825, em Portugal, com o poema Camões. No prefácio dessa obra, o autor admite que a essência do poema é romântica, entretanto, pede que não o filiem nem ao Classicismo, muito menos ao Romantismo. Dessa forma, Garrett pode ser considerado um romântico moderado, um escritor com características ainda neoclássicas e fortemente marcadas por um comprometimento.

Extensão desse comprometimento é sua literatura que, engajada, apresenta um claro projeto a ser perseguido: a crítica à sua contemporaneidade por meio de uma cuidadosa leitura do passado.

De todos os meios artísticos, Garrett elegerá o teatro como basilar, tanto para levar sua voz liberal quanto para colocar em cena o projeto engajado de sua dramaturgia: o passado como modelo e também como leitura alegórica de sua contemporaneidade. Esse projeto, concretizado com as peças Catão (1821), Um auto de Gil Vicente (1838), Filipa de Vilhena (1840) e $O$ alfageme de Santarém (1842), fora esboçado em 1819, no prefácio da tragédia Afonso de Albuquerque.

O objetivo deste artigo é revelar como se dá tal leitura na peça Catão, retratando o engajamento de Garrett. Para levar a cabo essa dramaturgia interveniente, havia um plano estabelecido

1 Doutor em Literatura Portuguesa, USP/SP, professor de Literatura Portuguesa e Teoria da Literatura na Universidade do Centro-Oeste do Paraná, UNICENTRO, campus Irati, DELET. E-mail: jeremoabo@ig.com.br. 
que, proposto na incompleta Afonso de Albuquerque, consistia em oferecer à sociedade coeva um espelho em que se mirasse e obtivesse daí duplo "ensinamento": com um passado modelar, cabia aos portugueses ou imitar a grandeza desse passado ou não reeditar seus erros.

Aos vinte anos de idade, Garrett fez uma confissão que iria tornar-se uma profissão de fé. Segundo ele, o poeta deveria ser também cidadão politicamente consciente. Estabeleceram-se a partir de então duas facetas inseparáveis na obra garrettiana, sobretudo na teatral: a do artista e a do homem político. Dessa forma, sua obra só poderia ser evidentemente engajada, não no sentido meramente panfletário, mas naquele sentido clássico de docere cum delectare. Para cumprir sua meta, o autor vai desenvolver, desde cedo, um projeto, perseguido de forma intensa e burilada até que ele produza sua obra-prima: Frei Luís de Sousa (1844).

Já no prefácio de Afonso de Albuquerque (1819) esboça-se esse projeto cujo objetivo, num primeiro momento, seria despertar nos leitores anseios de virtude, consciência e cidadania por meio de heróis antigos. Em 1822, ano da publicação de Catão, fazia Garrett uma confissão sincera e apaixonada a respeito da literatura dramática:

Conheço perfeitamente as dificuldades de uma composição dramática. Empregando a maior parte de minhas horas vagas - únicas que dou a versos e semelhantes passatempos - neste ramo da poesia que por inclinação amei e por estudo cultivo, versando quase desde a infância, com noturna e diurna mão, os teatros antigos e modernos, tenho de sua leitura constante colhido, quase menos, o conhecimento da dificuldade do gênero. (GARRETT, 1904, p. 1608, v.I)

Se o gênero dramático é para Garrett de grande dificuldade, por que sua preferência pelo teatro? 
Pode-se aventar a seguinte resposta: o apego de Garrett pelo teatro deve-se ao seu comprometimento político, além da crença de que a arte dramática precisa ser "útil à coletividade".

Para Garrett, e graças à sua formação clássica, a arte deveria ser portadora de uma noção extremamente moralizadora. Essa ideia será retomada anos mais tarde, quando o autor, já um romântico moderado, afirma, em 1843, que cabe ao drama revestir-se "das formas mais populares e derramar assim pelas nações um ensino fácil, uma instrução intelectual e moral que, sem aparato de sermão ou prelecção, surprenda os ânimos e os corações da multidão, no meio de seus próprios passatempos". (Idem: p. 1086). Essa função moralizadora deve ser o escopo de toda obra, sobretudo o teatro, cuja função seria a de espelhar os problemas da sociedade, tendo a vantagem sobre as outras manifestações artísticas de atingir um público maior.

Levado por tais considerações, Garrett dá à cena portuguesa a tragédia Catão; peça-chave, porque, de forma um pouco mais amadurecida, põe em prática o projeto defendido em Afonso de Albuquerque. O autor vai ler sua contemporaneidade de forma especular, à luz de um passado exemplar:

No Catão senti outra coisa, fui a Roma; e fiz-me romano quanto pude, segundo o ditado manda: mas voltei para Portugal, e pensei de português para portugueses: e a isso atribuo a indulgência e boa vontade do público que me ouviu e me leu. (Ibid., p. 1617 , v. II)

Como se percebe, com o propósito de um teatro cuja função seria a edificação moral, Garrett vai valer-se do teatro histórico. Num momento inicial, a fonte será o mundo grecoromano, escolha justificada pela formação clássica do dramaturgo.

\footnotetext{
${ }^{2}$ Expressão cunhada na obra de Ofélia M.C. Paiva Monteiro (1971, p. 327, v. I). Segundo a autora, Garrett via na poesia os "prazeres da solidão" e no teatro o casamento perfeito entre o prazer individual, a feitura do drama, e o coletivo, o espetáculo que exigiu um público.
} 
Ao publicar Catão, edição de 1822, o autor afirmava, no prólogo:

Outras [peças] tinha eu de mais antiga data; mas sobre carecerem de grande emenda, e lha não poder eu fazer agora, acresce mais analogia desta com as presentes idéias e o meu conceito, talvez errado, da sua melhoria. (Ibid., p 1617, v. II)

O próprio dramaturgo confessa que Catão estava em perfeita sintonia com os últimos acontecimentos em Coimbra; e as ideias erradas, numa clara alusão aos dois regimes políticos à época (Absolutismo e Liberalismo), ele tentaria corrigi-las por meio da peça. No prefácio da segunda edição da obra, em 1830, Garrett admite que a intenção é a moralidade política:

O assunto é o mais nobre, mais histórico e mais trágico de toda a história antiga e moderna. Representando as últimas agonias da mais solidamente constituída República da Antiguidade, - a moralidade política do drama naturalmente reflete muita lua sobre a grande questão que ora revolve o mundo e mostra (talvez mais claro que nenhuns tratados) a superioridade das modernas formas representativas e a excelência da liberdade constitucional ou monárquica. (Ibid., p.1615, v. I)

Para tal propósito, o autor recorre aos anais da história romana (47 a.C) para de lá trazer um dilema que, não obstante distanciado pelo tempo, iguala romanos e portugueses: o confronto entre duas concepções político-governamentais Absolutismo versus Liberalismo (em Portugal) e República versus Ditadura (em Roma). Na óptica garrettiana, elas se equivaleriam ao tratarem da maior ou menor participação da vontade popular no processo político. É nesse contexto que Garrett apresenta um passado (o romano) que serve de modelo e exemplo para o presente (o português). Se o presente não é satisfatório, cabe ao artista fazer uma leitura crítica, oferecendo à sociedade coeva uma leitura alegórico-crítica.

Tem-se, portanto, uma situação especular. Roma, em 47 a.C., vivia um delicado momento. Depois de combater os 
seguidores de Pompeu na Ásia, no Egito e na Espanha, César voltou a Roma, desejando ser recebido triunfalmente pela multidão e pelo Senado (baluarte da democracia). O intuito de César era tornar-se ditador vitalício, ou seja, substituir a República por um absolutismo monárquico-imperial.

Portugal, em 1820, vivia a mesma angústia. A burguesia liberal portuguesa só se instalaria no poder ao fim de catorze anos de lutas (1820-1834), por vezes renhidas e complexas, marcadas por uma alternância de vitórias e derrotas entre as duas facções da cena política de então: Liberais e Absolutistas. Não queria Garrett especularmente representar essas duas facções com Catão e César?

Em Catão, a grande discussão é o embate entre duas correntes políticas: de um lado, a Monarquia de César e, de outro, a República, representada pelo Senado, na figura do seu líder, Catão.

A peça é composta em versos decassílabos brancos. Seus cinco atos foram representados pela primeira vez no Teatro do Bairro Alto, em Lisboa, "por uma sociedade de curiosos", em 1821. Vinda a lume em 1822, a tragédia só obteve a glória literária em Plymouth, na Inglaterra, em 1828.

A história versa acerca de César, que está prestes a invadir Utica. O Senado Romano, após a derrota de Pompeu, prepara-se, com parcos recursos, para combater César, que tem como objetivo tornar-se imperador de Roma, posição que o Senado julga aviltante. O grande homem do Senado é Catão, ferrenho republicano, cuja posição política é intransigente. Reúne-se o Senado para debater acerca da crise do momento, uma vez que urge saná-la: dialogar ou não com César, que tinha como hábito perdoar os vencidos, oferecendo-lhes asilo político, o que, para Catão, é afrontoso. Entre os senadores, há antagonismo de ideias. Para Mânlio, é necessário ouvir César, caso contrário, a carnificina será inevitável. Bruto deseja guerra e para Semprônio é necessário dar a Catão plenos poderes para resolver a questão. Catão, como 
líder político, deixa clara a sua opção: liberdade ou morte. $O$ exército de César invade Utica e a derrota é certa. Catão sugere que fujam e peçam exílio aos Númidas, enquanto ele, tomado de patriotismo e de amor à liberdade, suicida-se, em protesto à tirania apresentada por César.

Como se pode constatar, as personagens são a representação viva de modalidades políticas e o natural antagonismo que resulta daí. Num primeiro plano, há duas facções totalmente opostas dentro do Império Romano: República versus Monarquia - Catão e César. Num segundo plano, divergências entre os membros de um mesmo partido político: Marcus Bruto, o mancebo ardente e puritano, representando a impetuosidade irrefletida e perigosa; Mânlio, austero, mas contemporizador; e Catão, o equilibrado, o político frio e comedido, cujo pensamento difere do de Bruto e Mânlio.

Ocorre então uma pergunta: não estaria Garrett fazendo uma alusão aos três partidos que estavam no cenário político português, em $1821 ?^{3}$

Mânlio, o velho senador, é comedido, avesso à violência e anseia pela paz. Insiste na ideia de que é preciso fazer voltar "aquela honra antiga/Doutros tempos" (ato I), e de que sem o fortalecimento do espírito "nestas ideias de passada glória" (ato II, cena I), tudo é vão.

É aquele, portanto, que se volta para o glorioso passado histórico e tenta mostrar aos seus compatriotas a lição que daí se pode tirar:

\footnotetext{
${ }^{3} \mathrm{O}$ partido dos radicais ou jacobinos, quase republicanos, pedreiros-livres, ideólogos sem malícia, ingênuos sem maldade, que destruíam tudo com a sua retórica balofa, inçada de fórmulas, princípios, doutrinas, quimeras, esperanças, visões. Era o dos miguelistas, o partido que tinha no paço a rainha e o infante, que tinha os conventos, todos os parasitas, todos os veneradores do passado católico e que estava reservado o futuro imediato, e o papel de consumador do desabamento final da nação. E por fim, o partido prático, moderado, conservador e monárquico, partido de uma minoria seleta que partilhava as opiniões correntes na Europa, restaurada pelos tratados de 1815. (MARTINS, 1968, p. 534)
} 
Liberdade! - Que é dela, a liberdade?/ Quanta nos daria Mário, Sila? - Quanta/ Nos daria Pompeu se triunfasse/ Com suas legiões volvesse ao Tibre!/ Roma, Roma, os teus dias são contados;/ Tu queres um senhor: tê-lo-ás. Os Quíncios/ Já não voltam. Sem honra, sem virtude/ Sem aquela pobreza santa e livre/ De Fabrício, onde vai a Liberdade! (ato I, cena II)

À luz de 1821, Mânlio representaria o partido moderado, conservador e monárquico. Bruto era o oposto de Mânlio. Ele encarna a demasiada crença na força e poder do Senado Romano ante a previsível investida de César; representaria o partido dos radicais e jacobinos.

Talvez o melhor retrato psicológico da peça resida em Catão. O caráter da personagem simbolizava o político inteligente e frio, visceralmente submetido à honra do seu credo político. É um ser excepcional que a tudo sacrifica em nome do "estrito cívico pundonor”. Diz-se que Garrett projetara em Catão a figura de Manuel Fernandes Tomás, o grande líder da Revolução de 1820.

A grande virtude de Catão incomoda Semprônio, homem de duas caras, amado pelo povo, que manobra como quer, para obter o que deseja ou, pelo menos, para matar um inocente, Pórcio, e abandonar a partida em seguida. É o traidor da causa democrática em busca de vantagens pessoais. O aspecto de traidor vil desta personagem será muito acentuado por Garrett. Segundo o pólo negativo da peça, suas características são previsíveis: alma invejosa, mesquinha e vingativa. Semprônio, em 46 a.C, fazia as vezes dos interesses conservadores do Absolutismo em 1821, o partido miguelista.

Não se pode esquecer de que a peça foi representada pela primeira vez em Lisboa, quando a Revolução Liberal já era fato consumado. Desse modo, não tinha como objetivo o incitamento à revolta, e sim um caráter pedagógico construtivo. Garrett chamava atenção e insistia no parentesco dos heróis da peça e dos espectadores: "Romanos estes são, - mas vois sois Lusos/ E de 
romano a portugueses que dista?” (GARRETT, 1904, p. 1638, v. II)

A distância temporal (47 a.C/ 1821) dilui-se na igualdade do dilema Liberdade Constitucional/Ditadura Cesaréa ou Miguelista vivido por romanos no passado e portugueses em sua contemporaneidade.

No ato V, cena VII, há claras alusões à Península: “Ou além das indômitas Espanhas", ou ainda: "Das Espanhas, inda não subjugadas, nos convida".

Que César será o vencedor, não resta dúvida. No entanto, há uma esperança de reviravolta, que dará aos vencidos de agora a vitória futura. A maior lição que se pode tirar da peça é de moderação, de conselho para uma organização posterior à sublevação. Estaria Garrett, nesse momento, sentindo que os vintistas não traziam preparação suficiente para a reconstrução política de Portugal que efetivamente só se concretizaria em 09 de setembro de 1836 ?

Garrett coloca na fala de sua personagem exemplar sua crença política, que não poderia ser outra coisa: a moderação de um homem que desejava ver em seu país o regime liberal parlamentar.

Saltam aos olhos nas falas de Catão o repúdio à tirania, o império da Lei sobre a vontade absolutista de um Rei. Ao cabo, o preceito básico que alicerçaria a Constituição de 1822, que limitava o poder real na medida em que representava a supremacia do poder parlamentar sobre o do rei.

- Um tirano é sem dúvida, na terra O malvado maior: mas nem por isso Te é lícito puni-lo. Magistrados Que o julguem, leis que o punam - com algozes Para as executar - tem a República. Usurpas também tu se teu juiz privado De públicas ofensas te instituis. (ato IV, cena III)

Com essa peça histórica, Garrett conseguiu alcançar vários intuitos: agitar sentimentos atuais por meio de heróis antigos; 
suscitar o sentimento de liberdade e o de ódio à tirania; evitar confrontos com a censura, uma vez que o herói disfarçado à romana inspirava menos receios e menos aborrecimentos ao autor; colocar sua arte a serviço da Revolução Liberal; e, sobretudo, refletir um problema do seu tempo (1821-Liberalismo versus Absolutismo) à luz alegórica de situações pretéritas. De outro lado, procurou ler sua contemporaneidade, examiná-la, criticá-la de forma especular à luz de um passado exemplar, no caso, o passado romano.

A opção pelo teatro talvez se deva à crença de que "o teatro é um grande meio de civilização" e "a literatura dramática é, de todas, a mais ciosa de independência nacional" (GARRETT', Op. cit., p. 157)

Em síntese, Garrett, em Catão, fez uma leitura alegórica do seu tempo coevo via situações pretéritas modelares.

Fica claro o mecanismo de alegoria na obra, pois sob a fábula romana, recuada no espaço e no tempo, oculta-se um sentido que tem a ver com sua contemporaneidade e que se desvela à medida que se descobrem equivalências e correlação entre a realidade dita e referida (tirania versus Senado, em 47 a.C) e a que se esconde por trás (Liberalismo versus Absolutismo, em 1818-1822).

Por fim, vale dizer que a dramaturgia garrettiana, como leitura de sua contemporaneidade, visa a ser a memória do esquecimento: o exame crítico de um conturbado período que, marcado pelo esquecimento das lições pretéritas ou não, procura imitar-lhe as glórias e grandezas, ou reedita-lhes os erros.

\section{BIBLIOGRAFIA CITADA:}

BARATA, José Oliveira. História do teatro português. Lisboa, Universidade Aberta, 1991.

BRAGA, Teófilo. Garrett e o Romantismo. Porto, Chardron, 1903.

GARRETT, Almeida. Obras completas. Grande Edição Popular Ilustrada. Prefaciada, revista, coordenada e dirigida por Teófilo Braga. Lisboa, Empresa Histórica de Portugal, 1904.

Catão. Tragédia. Obras I. (Teatro I). Lisboa, Imprensa Liberal, 
MARTINS, Oliveira. História de Portugal. Lisboa, Guimarães Editores, 1968.

MONTEIRO, Ofélia M.C. Paiva. A formação de Almeida Garrett: experiências e criação. Coimbra, Centro de Estudos Românicos, 1971. V. I e II.

SARAIVA, José Hermano. História de Portugal. Lisboa, Publicações Europa-América, 1993.

Abstract: We know that Garrett was an author compromised with his time and his dramaturgical work will be, therefore, the picture of such an engagement. Due to his classical background, his first productions, throughout an exemplary past life, obtained from the Greek-Roman world, focus on analyzing his present moment. This exemplary past, which looks on correcting the present, will be showed in the play Catão, which is the objective of this article.

Keywords: Garrett; dramaturgy; allegory. 